\title{
Tinjauan Hukum Penerapan Akad Ijarah dan Inovasi Dari Akad Ijarah Dalam Perkembangan Ekonomi Syariah di Indonesia
}

\author{
Nadhira Wahyu Adityarani \& Lanang Sakti, \\ e-mail: nadhiraadityarani@universitasbumigora.ac.id, \& lanang@universitasbumigora.ac.id \\ Dosen Prodi S1 Hukum Universitas Bumigora
}

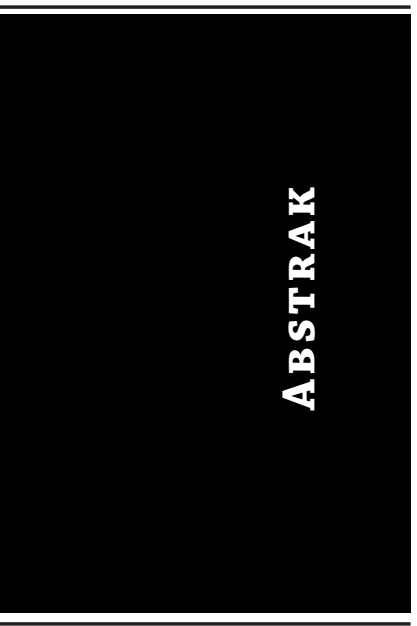

One of the islamic products offered to public is the principle of lease or (ijarah) included of muamalah. Principle of ijarah that offered to public based on an agreement (contract). Muamalah transactions through ijarah have experienced new developments and breakthroughs in the world of modern banking, such as "Ijarah operational lease" and "ijarah financial lease" as usually applied in the Islamic banking system. Now has been progressing with the implementation of ijarah in the system of the islamic capital market that shaped the sukuk or Islamic bonds, so there needs to be study more about the legal aspect in application of ijarah and innovation contract of ijarah with development of economic syariah in Indonesia. In this study showed the development of economic system is not only in Islamic banking system but in the Islamic capital market system by using ijarah contract. This application has created innovations in the principles of ijarah, such as contract of ijarah muntahiah bit tamlik, sukuk ijarah and sukuk ijarah SBSN

\section{Kayword : Contract, Ijarah, Innovation}

Salah satu produk syariah yang ditawarkan kepada masyarakat adalah prinsip sewa-menyewa atau ijarah yang termasuk ke dalam ruang lingkup muamalah. Prinsip ijarah yang ditawarkan kepada masyarakat didasarkan pada sebuah perjanjian (akad). Transaksi muamalah melalui ijarah mengalami perkembangan dan terobosan baru dalam dunia perbankan modern, seperti ijarah operational lease dan ijarah berbentuk financial lease yang biasanya diterapkan dalam sistem perbankan syariah, sekarang telah mengalami perkembangan dengan diterapkannya ijarah dalam sistem pasar modal syariah yang berbentuk sukuk atau obligasi Syariah, sehingga perlu ada kajian lebih lanjut terkait bagaimana tinjauan hukum penerapan akad ijarah dan inovasi dari akad ijarah dalam perkembangan ekonomi syariah di Indonesia. Penelitian ini menggunakan metode penelitian hukum normatif dengan menggunakan metode pendekatan yuridis normatif yang mengacu pada hukum dan peraturan perundang-undangan yang berlaku. Dalam penelitian ini menunjukkan bahwa perkembangan sistem perekonomian tidak hanya dalam sistem perbankan syariah saja melainkan dalam sistem pasar modal syariah, akad ijarah ini digunakan. Penerapan ini menciptakan inovasi dalam prinsip-prinsip ijarah, seperti akad ijarah muntahiah bit tamlik, sukuk ijarah dan sukuk ijarah SBSN

\section{PENDAHULUAN}

Kata Kunci: Akad, Ijarah, Inovasi

Salah satu sistem perekonomian yang penting dalam pembangunan suatu negara adalah adanya dukungan dari sistem keuangan yang sehat dan stabil. Demikian pula dengan negara Indonesia. Sistem keuangan negara Indonesia sendiri terdiri dari tiga unsur, yakni sistem moneter, sistem perbankan, dan sistem lembaga keuangan bukan bank. ${ }^{[1]}$

\footnotetext{
1 Jamal Wiwoho, 2014, "Peran Lembaga Keuangan Bank dan Lembaga Keuangan Bukan Bank dalam Memberikan Distribusi
} 
Perekonomian yang berkembang saat ini masih berada di bawah dua kekuatan besar, yakni sistem kapitalisme dan sosialisme. Sementara ekonomi Islam yang lebih mempertimbangkan faktor nilai, karakter luhur manusia, keutuhan sosial, dan pembalasan Allah SWT di akhirat justru perkembangannya lebih lambat. Dalam kacamata Islam, kegiatan ekonomi tidak hanya semata-mata untuk memenuhi kebutuhan materi, tetapi juga harus memiliki nilai ibadah.

Sudah cukup lama umat Islam Indonesia, demikian juga belahan dunia islam (muslim world) lainnya, menginginkan sistem perekonomian yang berbasis nilai-nilai dan prinsip syariah (Islamic Economic System) untuk dapat diterapkan dalam segenap aspek kehidupan umat. Perkembangan awal perekonomian yang berbasis Islam di Indonesia adalah dengan lahirnya bank islam di Indonesia, yaitu Bank Muamalat Indonesia.

Keberadaan bank Islam di Indonesia, pada awalnya belum mendapatkan perhatian yang optimal dalam perbankan nasional. Meskipun, demikian Bank Muamalat sebagai bank Islam pertama yang lahir di Indonesia menunjukkan keberadaanya dengan membuktian bahwa bank Islam di Indonesia dapat bertahan dalam gejolak krisis ekonomi 1997an yang dialami Negara pada saat itu. ${ }^{[2]}$

Hal tersebut menjadikan perkembangan perbankan syariah saat ini seolah-olah telah menjamur di wilayah Indonesia, berbagai bank telah hadir untuk menyediakan fasilitas perbankan dengan sistem syariah. Lembaga Keuangan Syariah (LKS), secara garis besar alur operasionalnya mulai dari penghimpunan dana, penyaluran dana sampai dengan pembagian hasil usaha sesuai dengan prinsip syariah. Lembaga Keuangan Syariah dilihat dari konsep syariahnya, baik Bank Umum Syariah (BUS), Kantor Cabang Syariah bank konvensional/Unit Usaha Syariah (UUS), Bank Pembiayaan Rakyat Syariah (BPRS), maupun Ba'itul Maal wat Tamwil (BMT), tidaklah berbeda. Perbedaannya adalah pada skala bisnisnya saja. ${ }^{[3]}$

Majelis Ulama Indonesia (MUI) sebagai payung dari lembaga dan organisasi keIslaman, menganggap perlu dibentuknya satu lembaga khusus bernama Dewan Syariah Nasional (DSN). Dewan Syariah Nasional mempunyai fungsi mengatur tugas dalam kegiatan usaha Lembaga Keuangan Syariah sesuai dengan Syariah Islam yang disusun dan ditentukan dalam bentuk Fatwa, serta sebagai peneliti bagi produk-produk yang dikembangkan oleh Lembaga Keuangan Syariah (LKS). Lembaga Keuangan Syariah dalam menjalankan alur operasional dan konsep syariahnya, dikenal adanya sebuah lembaga pengawas yang disebut Dewan Pengawas Syariah (DPS) yang bertugas untuk mengawasi lembaga tersebut. ${ }^{[4]}$ Eksistensi Dewan Pengawas Syariah merupakan pelaksanaan tugas untuk mengawasi produk lembaga keuangan sesuai dengan prinsip syariah.

Undang-Undang Nomor 21 Tahun 2008 tentang Perbankan Syariah, ditegaskan bahwa Bank Keadilan Bagi Masyarakat”, Jurnal Masalah Masalah Hukum (MMH), Universitas Diponegoro, Vol. 43 No. 1, Semarang, hlm. 8789

2 Profil Bank Muamalat, Tentang Profil Bank Muamalat, https://www.bankmuamalat.co.id/profil-bank-muamalat diakses pada tanggal 4 Juni 2020

3 Wiroso, 2005, Jual-beli Murabahah, UII Press, Yogyakarta. hlm. 5

4 Muhammad Syafi'i Antonio, 2001, Bank Syariah: Dari Teori ke Praktik, GemaInsani Press, Jakarta. hlm. 32 
Syariah adalah bank yang menjalankan kegiatan usahanya berdasarkan prinsip syariah dan menurut jenisnya terdiri atas Bank Umum Syariah dan Bank Pembiayaan Rakyat Syariah. ${ }^{[5]}$

Bank berdasarkan prinsip syariah, seperti halnya bank konvensional juga berfungsi sebagai intermediary financial, yaitu lembaga yang menghimpun dana dari masyarakat dalam bentuk simpanan, lembaga yang menyalurkan kembali dana-dana yang sudah terkumpul tersebut kepada masyarakat yang membutuhkannya dalam bentuk fasilitas pembiayaan dan lembaga yang melakukan pemberian jasa pelayanan perbankan syariah. Bedanya hanyalah bahwa bank syariah melakukan kegiatan usahanya tidak berdasarkan bunga (interest free), tetapi berdasarkan prinsip syariah yaitu prinsip pembagian keuntungan dan kerugian atau yang sering disebut dengan prinsip bagi-hasil atau Profit and Loss Sharing Principle (PLS principle). ${ }^{[6]}$

Salah satu fungsi dari intermediary financial adalah penyaluran dana. Bentuk penyaluran dana yang diberikan oleh bank dapat melalui beberapa prinsip, yaitu prinsip jual-beli, prinsip bagihasil, prinsip sewa-menyewa dan prinsip pinjam-meminjam. ${ }^{[7]}$ Salah satu bentuk penyaluran dana melalui prinsip sewa-menyewa adalah pembiayaan ijarah. Ijarah adalah Akad sewa menyewa barang antara kedua belah pihak, yaitu Bank (Mu'jjir) dengan Nasabah (Musta'jir) sebagai penyewa suatu barang milik Bank, untuk memperoleh manfaat atas barang yang disewa. ${ }^{[8]}$

Perkembangan dunia bisnis makin pesat dengan di dukung oleh teknologi dan keilmuan yang semakin berkembang pula. Bisnis yang telah berkembang mempunyai aturan main yang telah diatur dalam peraturan perundang-undangan, dikenal dengan istilah hukum bisnis. Di Indonesia, bisnis syariah pun telah berkembang. Perkembangan tersebut memberikan kontribusi yang cukup besar terhadap pembangunan perekonomian di Indonesia. Perkembangan ini harus mendapatkan apresisasi dengan dibentuknya regulasi yang berdasarkan pada prinsip syariah.

Prinsip sewa-menyewa atau ijarah termasuk ke dalam ruang lingkup muamalah. Muamalah merupakan peraturan yang mengatur hubungan antara sesama manusia. Seiring dengan perkembangan zaman, transaksi muamalah yaitu ijarah mengalami perkembangan dan terobosan baru dalam dunia modern. Sebagai contoh, ijarah yang telah dikenal dan telah ada teori yang membahasnya, yaitu ijarah berbentuk operational leas $e^{[9]}$ dan ijarah berbentuk financiallease ${ }^{[10]}$ yang biasanya diterapkan dalam sistem perbankan syariah, sekarang telah mengalami perkembangan yaitu telah diterapkannya ijarah dalam sistem pasar modal syariah yang berbentuk sukuk atau

\footnotetext{
No. 94

5 Pasal 1 angka 7 Undang-Undang Nomor 21 tahun 2008 tentang Perbankan Syariah. Lembaran Negara RI Tahun 2008

6 Sutan Remy Sjahdeini, 1999. Perbankan Islam dan Kedudukannya dalam Tata Hukum Perbankan Indonesia, Grafiti, Jakarta, hlm. 1

7 Mardani, 2010. Hukum Ekonomi Syariah di Indonesia, Refika Aditama, Jakarta, hlm. 144

${ }^{8}$ Website Bank Muamalat, Edukasi Perbankan, Mengenal Akad Perbankan Syariah, https://www.bankmuamalat.co.id/ edukasi-perbankan/mengenal-akad-perbankan-syariah diakses pada tanggal 4 Juni 2020

${ }^{9}$ Ijarah adalah akad untuk memanfaatkan jasa, baik jasa atas barang ataupun jasa atas tenaga kerja. Ijarah yang pada akhir masa perjanjian, objek sewa akan kembali menjadi milik pihak yang menyewakan (musta'jir). Artinya tidak terjadi pemindahan kepemilikan aset, baik di awal ataupun di akhir perjanjian. Ijarah ini sering disebut sebagai operation lease

${ }^{10}$ Ijarah Muntahiah bit Tamlik (IMBT) adalah sejenis perpaduan kontrak jual-beli dan sewa atau lebih tepatnya akad sewa yang diakhiri dengan kepemilikan barang di tangan di penyewa. IMBT hanya dapat memanfaatkan berupa barang saja dan akan terjadi pemindahan kepemilikan aset karena di awal perjanjian telah ditetapkan untuk diakhiri dengan kepemilikan. Ijarah ini sering disebut sebagai financial lease
}

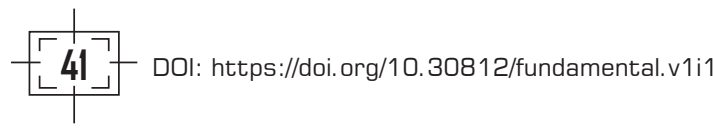


obligasi syariah.

Prinsip ijarah, baik dalam sistem perbankan syariah maupun dalam sistem pasar modal syariah didasarkan pada sebuah perjanjian (akad). Perjanjian atau akad dalam islam adalah pertemuan ijab dan kabul sebagai pernyataan kehendak dua pihak atau lebih untuk melahirkan suatu akibat hukum pada objeknya. ${ }^{[11]}$ Perjanjian yang telah terjalin di antara para pihak dengan memperhatikan syarat sah perjanjian memunculkan hak dan kewajiban yang harus dipenuhi. Hal ini mempunyai akibat hukum bagi para pihak yaitu perjanjian yang telah disepakati bersama mengikat bagi yang membuatnya layaknya undang-undang (asas pacta sunt servanda), sehingga apabila salah satu pihak tidak melakukan kewajibannya, maka pihak yang lain bisa meminta ganti-rugi atau yang disebut sebagai wanprestasi. ${ }^{[12]}$

Berdasarkan penjelasan di atas dapat ditarik rumusan masalah, yaitu Pertama, bagaimana tinjauan hukum penerapan akad ijarah dan Kedua, inovasi dari akad ijarah dalam perkembangan ekonomi syariah di Indonesia.

\section{METODE PENELITIAN}

Dalam mengkaji permasalahan tersebut penulis menggunakan penelitian hukum normatif yang pada dasarnya merupakan suatu kegiatan yang akan mengkaji aspek-aspek internal dari hukum positif dan metode ini menggunakan pendekatan yuridis normatif artinya suatu pendekatan yang mengacu pada hukum dan peraturan perundang-undangan yang berlaku. ${ }^{[13]}$

\section{PEMBAHASAN}

\section{A. Tinjauan Hukum Penerapan Akad Ijarah}

Ijarah adalah akad pemindahan hak guna atas barang atau jasa, melalui pembayaran upah sewa, tanpa diikuti dengan pemindahan kepemilikan atas barang itu sendiri. ${ }^{[14]} \mathrm{Hal}$ ini sesuai dengan pengertian ijarah menurut Fatwa DSN-MUI No. 09/DSN-MUI/IV/2000 tentang Pembiayaan Ijarah, yaitu ijarah adalah akad pemindahan hak guna (manfaat) atas suatu barang atau jasa dalam waktu tertentu melalui pembayaran sewa/upah, tanpa diikuti dengan pemindahan kepemilikan barang itu sendiri. ${ }^{[15]}$

Dalam hukum islam, istilah orang yang menyewakan disebut mu'jir, sedangkan orang yang menyewa/ penyewa disebut musta'jir, dan benda yang disewakan disebut ma'jur, serta uang sewa atau imbalan atas pemakaian manfaat barang disebut ujrah. ${ }^{[16]}$

11 Syamsul Anwar, 2007. Hukum Perjanjian Syariah Studi tentang Teori Akad dalam Fikih Muamalat, PT. RajaGrafindo Persada, Jakarta, hlm. 68

12 Ridwan Khairandy, 2004, Itikad Baik dalam Kebebasan Berkontrak, Program Pascasarjana Fakultas Hukum Universitas Indonesia, Jakarta, hlm. 84

${ }^{13}$ Bambang Sunggono, 2003. Metodologi Penelitian Hukum, PT RajaGrafindo Persada, Jakarta, hlm.32

${ }^{14}$ Muhammad Syafi'i Antonio, Op., cit, hal. 117

${ }^{15}$ DSN-MUI bersama BI, 2001. Himpunan Fatwa Dewan Syariah Nasional untuk Lembaga Keuangan Syariah, Edisi Pertama, DSN-MUI bersama BI, Jakarta, hlm. 55

${ }^{16}$ Abdul Ghofur Anshori, 2006. Pokok-pokok Hukum Perjanjian Islam di Indonesia, Citra Media, Yogyakarta. hal. 45 
Menurut Sayyid Sabiq, ijarah adalah suatu jenis akad yang mengambil manfaat dengan jalan penggantian. Ijarah terbagi kepada dua, yaitu: ${ }^{[17]}$

a. Ijarah yang berhubungan dengan sewa jasa, yaitu mempekerjakan jasa seseorang dengan upah sebagai imbalan jasa yang disewa. Pihak yang mempekerjakan disebut musta'jir, sedangkan pihak pekerja disebut 'ajir dan upah yang dibayarkan disebut ujrah.

b. Ijarah yang berhubungan dengan sewa aset atau properti, yaitu memindahkan hak untuk memakai dari aset atau properti tertentu kepada orang lain dengan imbalan biaya sewa. Bentuk ijarah ini mirip dengan leasing (sewa-beli) pada konvensional. Pihak yang menyewa disebut musta'jir, pihak yang menyewakan disebut mu'jir dan biaya sewa disebut ujrah.

1. Landasan hukum ijarah:

a) Al-Qur'an

QS. Ath-Thaalaq (65): 6

"Kemudian jika mereka menyusukan (anak-anak)mu untukmu, maka berikanlah kepada mereka upahnya."

QS Al-Qashash (28): 26

"Salah seorang dari kedua wanita itu berkata, Ya Bapakku ambillah ia sebagai orang yang bekerja (pada kita), karena sesungguhnya orang yang peling baik yang kamu ambil untuk bekerja (pada kita) ialah orang yang kuat lagi dapat dipercaya."

b) Al-Hadits

Hadits riwayat Ibnu Majah:

"Berikanlah upah kepada orang yang kamu pakai tenaganya sebelum keringatnya kering."

c) Undang-Undang Nasional dan fatwa Dewan Syariah Nasional

a. Undang-undang No.19 Tahun 2008 tentang Surat Berharga Syariah Negara;

b. Fatwa NO: 41/DSN-MUI/III/2004 tentang Obligasi Syari'ah Ijarah

c. Fatwa NO: 69/DSN-MUI/VI/2008tentang Surat Berharga Syariah Negara;

d. Fatwa No 71/DSN-MUI/IV2008 tentang akad sale and lease back;

e. Fatwa No: 72/DSN-MUI/VI/2008 tentang Surat Berharga Syariah Negara ijarah sale and lease back;

f. Fatwa No: 76/DSN-MUI/ VI/2010 tentang SBSN ijarah asset to be leased;

g. Fatwa DSN-MUI No. 27/DSN-MUI/III/2002 tentang Ijarah Muntahiyah Bit at-Tamlik (IMBT);

h. Fatwa DSN-MUI No. 09/DSN-MUI/IV/2000 tentang Pembiayaan Ijarah;

i. Fatwa DSN-MUI No. 27/DSN-MUI/III/2002 tentang Ijarah Muntahiyah Bit at-Tamlik (IMBT).

2. Rukun dan Syarat-syarat Ijarah

Secara yuridis agar perjanjian sewa menyewa memiliki kekuatan hukum, maka perjanjian tersebut harus memenuhi rukun dan syarat-syaratnya. Unsur terpenting, yaitu kedua pihak cakap bertindak dalam hukum yakni memiliki kemampuan untuk dapat membedakan yang

${ }^{17}$ Ascara, 2008, Akad dan Produk Bank Syariah, Jakarta: PT Raja Grafindo Persada, hlm. 99. 
baik dan buruk (berakal) serta dewasa (baligh). Rukun sewa menyewa terdiri dari adanya para pihak sebagai subjek hukum (mu'jir dan musta'jir), terdapat barang yang disewakan dan harus ada ijab qabul dari para pihak. ${ }^{[18]}$

Sedangkan untuk sahnya perjanjian sewa-menyewa harus terpenuhi syarat-syarat sebagai berikut: ${ }^{[19]}$

a. Mu'jir dan musta'jir telah tamyiz ( \pm berumur 7 tahun), berakal, sehat, dan tidak dalam pengampuan

b. Mu'jir adalah pemilik sah dari barang sewa, walinya atau orang yang menerima wasiat (washiy) untuk bertindak sebagai wali

c. Masing-masing pihak rela untuk melakukan perjanjian sewa-menyewa. Bahwa di dalam perjanjian sewa-menyewa tidak boleh mengandung unsur paksaan karena dengan adanya paksaan menyebabkan perjanjian yang dibuat menjadi tidak sah.

d. Harus jelas dan terang mengenai objek yang diperjanjikan bahkan objek tersebut telah benar-benar milik mu'jir

e. Objek sewa menyewa dapat digunakan sesuai dengan peruntukannya atau mempunyai nilai manfaat

f. Objek sewa menyewa dapat diserahkan

g. Kemanfaatan objek yang diperjanjian adalah yang diperbolehkan oleh agama

h. Harus ada kejelasan mengenai berapa lama suatu barang itu akan disewakan dan harga sewa atas barang tersebut.

3. Hak dan kewajiban Para Pihak

Akad ijarah menimbulkan hak dan kewajiban bagi para pihak yang membuatnya. Hak dan kewajiban tersebut, dirincikan sebagai berikut: ${ }^{[20]}$

1). Mu'jir

a) Ia wajib menyerahkan barang yang disewakan ma'jur kepada musta'jir

b) Memelihara ma'jur sehingga ma'jur dapat dipakai untuk keperluan yang dimaksudkan

c) Memberikan musta'jir kenikmatan/manfaat atas ma'jur selama waktu berlangsungnya sewa-menyewa

d) Menanggung musta'jir terhadapa semua cacat dari ma'jur yang merintangi pemakaian barang

e) Ia berhak menerima ujrah yang besarnya sesuai diperjanjikan

f) Ia berhak menerima kembali ma'jur di akhir masa akad seperti semula

2) Musta'jir

Ia wajib memakai ma'jur sebagai bapak rumah yang baik, sesuai dengan tujuan yang diberikan pada barang tersebut menurut perjanjiannya, ia wajib membayar ujrah sesuai diperjanjikan dan wajib mengembalikan ma'jur kepada mu'jir di akhir perjanjian seperti semula. Musta'jir berhak menerima manfaat dari ma'jur, ia juga berhak menerima ganti rugi jika terdapat cacat pada ma'jur, serta ia berhak tidak mendapatkan gangguan dari orang lain selama memanfaatkan ma'jur

Masing-masing pihak harus memenuhi prestasi, yaitu berupa:

(a) Memberikan sesuatu, yaitu mu'jir menyerahkan ma'jur dan musta'jir membayar ujrah

(b) Berbuat sesuatu, yaitu mu'jir memelihara ma'jur sehingga dapat dimanfaatkan dan musta'jir menjadi bapak rumah yang baik

(c) Tidak berbuat sesuatu, yaitu mu'jir dilarang selama masa sewa mengubah wujud ma'jur sehingga ma'jur berubah manfaatnya atau tidak dapat dimanfaatkan dan musta'jir

\footnotetext{
${ }^{18}$ Abdul Ghofur Anshori, Op., cit., hal. 46-47

${ }^{19}$ Ibid.

${ }^{20}$ Ibid.
} 
dilarang menggunakan ma'jur untuk kepentingan diluar yang diperjanjikan

Dalam hal akad ijarah, resiko mengenai objek perjanjian dipikul oleh pemilik barang (pihak yang menyewakan), sebab penyewa hanya mengusai untuk mengambil manfaat atau kenikmatan dari barang yang disewakan. Sehingga dalam hal terjadi kerusakan objek perjanjian maka resiko ditanggung oleh pemilik barang, kecuali kerusakan yang terjadi disebabkan oleh adanya kesalahan penyewa. ${ }^{[21]}$

Dalam hal musta'jir ingin menyewakan lagi barang sewaan kepada orang lain, hal tersebut diperbolehkan sepanjang syarat penggunaan barang sewaan sesuai dengan penggunaan yang dijanjikan ketika akad. Selain itu, dalam hal yang dapat membatalkan akad ijarah adalah apabila terjadi cacat pada ma'jur yang terjadi di tangan mu'jir, rusaknya ma'jur, terpenuhinya manfaat yang diakadkan, berakhirnya masa akad, ma'jur telah musnah atau dicuri. ${ }^{[22]}$

\section{B. Inovasi dari akad ijarah dalam perkembangan ekonomi syariah di Indonesia}

1. Ijarah

Ijarah adalah akad untuk memanfaatkan jasa, baik jasa atas barang ataupun jasa atas tenaga kerja. Bila digunakan untuk mendapatkan manfaat barang, maka disebut sewamenyewa. Sedangkan jika digunakan untuk mendapatkan manfaat tenaga kerja, disebut upah-mengupah. Pada ijarah, tidak terjadi perpindahan kepemilikan objek ijarah. Objek ijarah tetap menjadi milik pihak yang menyewakan.

Contoh: Pemilik kendaraan bermotor menyewakan kendaraannya dengan memperoleh imbalan uang sewa. Seorang mandor memperoleh upah dari manfaat tenaga kerja yang diberikan kepada pemilik proyek.

Selain itu, ijarah pada akhir masa perjanjian, objek sewa akan kembali menjadi milik pihak yang menyewakan (musta'jir). Artinya tidak terjadi pemindahan kepemilikan aset, baik di awal ataupun di akhir perjanjian. Ijarah ini sering disebut sebagai operation lease. ${ }^{[23]}$

2. Ijarah Muntahiah bit Tamlik

Ijarah Muntahiah bit Tamlik (IMBT). IMBT adalah sejenis perpaduan kontrak jual-beli dan sewa atau lebih tepatnya akad sewa yang diakhiri dengan kepemilikan barang di tangan di penyewa. ${ }^{[24]}$ IMBT hanya dapat memanfaatkan berupa barang saja dan akan terjadi pemindahan kepemilikan aset karena di awal perjanjian telah ditetapkan untuk diakhiri dengan kepemilikan. Ijarah ini sering disebut sebagai financial lease. ${ }^{[25]}$

Fatwa DSN-MUI No. 27/DSN-MUI/III/2002 tentang Ijarah Muntahiyah Bit at-Tamlik (IMBT), menyatakan bahwa:

\footnotetext{
${ }^{21}$ Subekti, 1995. Aneka Perjanjian, Cetakan Kesepuluh, PT. Citra Aditya Bakti, Bandung, hal. 44

${ }^{22}$ Hendi Suhendi, Op., cit., hlm 122

${ }^{23}$ Adiwarman Karim, 2007. Bank Islam Analisis Fiqih dan Keuangan, Edisi Ketiga, Rajawali Pers: Jakarta, hal. 143

${ }^{24}$ Muhammad Syafi'i Antonio, Op., cit, hlm 118

${ }^{25}$ Adiwarman Karim, Loc., cit.
} 
- Pihak yang melakukan al-Ijarah al-Muntahiah bi al-Tamlik harus melaksanakan akad Ijarah terlebih dahulu. Akad pemindahan kepemilikan, baik dengan jual beli atau pemberian, hanya dapat dilakukan setelah masa Ijarah selesai.

- Janji pemindahan kepemilikan yang disepakati di awal akad Ijarah adalah wa'd (الوعـد), yang hukumnya tidak mengikat. Apabila janji itu ingin dilaksanakan, maka harus ada akad pemindahan kepemilikan yang dilakukan setelah masa Ijarah selesai.

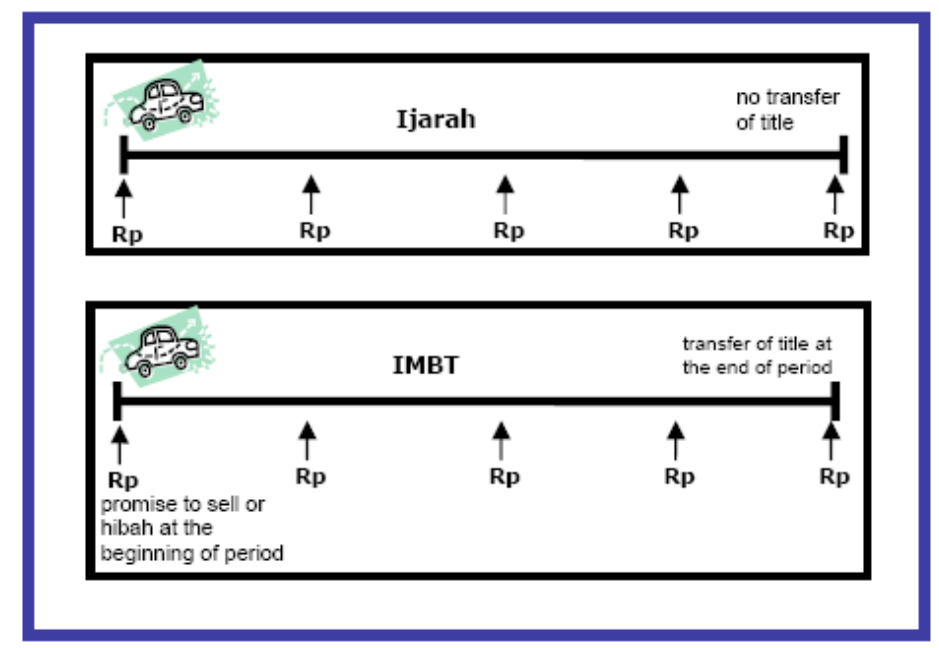

Tabel. 1 Perbedaan antara Ijarah dengan IMBT

3. Sukuk Ijarah

Sukuk Ijarah merupakan surat berharga yang merepresentasikan kepemilikan penyertaan atas asset yang disewakan. Sukuk ini memberikan hak kepada para pemegangnya untuk mendapatkan uang sewa serta hak untuk mengalihkan kepemilikan berdasarkan penyertaan yang mereka miliki tanpa mempengaruhi hak si penyewa, dengan kata lain sukuk ini dapat diperjual belikan. Para pemiliki sukuk menangung seluruh biaya perawatan dan kerusakan dari asset yang dimilki berdasarkan proporsi kepemilikan mereka. Accounting and Auditing Organisation For Islamic Financial Institutions (AAOIFI atau Organisasi Akuntansi dan Auditing Untuk Lembaga Keuangan Islam), Secara umum sukuk didefinisikan sebagai sertifikat pertisipasi Islami yang dapat diperdagangkan berdasarkan kepemilikan dan pertukaran dari asset yang disepakatibersama. ${ }^{[26]}$

Sukuk ijarah merupakan sekuritas yang mewakili kepemilikan aset yang keberadaannya jelas dan diketahui. Dalam kontrak ijarah penting bahwa baik aset yang disewa beli dan jumlah yang disewa diketahui dengan jelas oleh pihak-pihak yang terkait pada saat kontrak. Dalam akad ijarah, obyek ijarah dapat berupa manfaat aset dan pembayaran sewa atau manfaat jasa dan pembayaran upah.

Struktur sukuk ijarah sekurang-kurangnya ada tiga pihak yang terlibat di dalamnya yaitu: Originator atau penerima ijarah, Special purpose vehicle (penerbit sukuk ijarah) dan Investor Yogyakarta.

${ }^{26}$ Nazaruddin Abdul Wahid, 2010. Sukuk: Memahami dan Membedah Obligasi pada Perbankan Syariah, Ar-Ruzz Media, 
(sukuk holders). Prosedur sukuk ijarah ini adalah pengambil inisiatif membentuk Special Purpose Vehicle (SPV) yang merupakan suatu lembaga yang bebas dan kepadanya dijual aset. Dengan pengertian bahwa lembaga ini sebagai pengambil inisiatif untuk menyewakan aset tersebut dengan nilai sewa yang disepakati. Kemudian SPV mensekuritisasikan aset tersebut dengan menggunakan kontrak ijarah dan menjualnya kepada investor. Sertifikat ini memiliki nilai yang sama dengan hak milik dari tangible assets. Proses penjualan sukuk dimaksudkan untuk mendapatkan dana bagi SPV yang akan dibayarkan kepada pemilik aset (pemerintah). Selanjutnya disebabkan aset disewa kembali oleh originator, maka SPV berkewajiban mengumpulkan sewa dari originator untuk diserahkan kepada investor (sukukholder). Keuntungan dengan risiko yang rendah dan kemungkinan mudah untuk dijual melalui pasar sekunder (liquidity) merupakan pendorong bagi investor untuk membeli sukuk. ${ }^{[27]}$

Khusus untuk sukuk ijarah, kontrak yang mendasarinya adalah ijarah yaitu sewa menyewa seperti yang telah dijelaskan sebelumnya. Sebagaimana ketentuan transaksi bisnis syariah yang membedakannya dengan ketentuan transaksi bisnis konvensional, kegiatan sukuk ijarah tidak boleh bertentangan dengan syariah seperti : (a) Usaha perjudian dan permainan yang tergolong judi atau perdagangan yang dilarang; (b) Usaha lembaga keuangan konvensional (ribawi), termasuk perbankan dan asuransi konvensional; (c) Usaha yang memproduksi, mendistribusi, serta memperdagangkan makanan dan minuman haram; (d) Usaha yang memproduksi, mendistribusi, dan atau menyediakan barang-barang ataupun jasa yang merusak moral dan bersifat mudarat (Fatwa No. 20 DSN-MUI/IV/2001 tentang Pedoman Investasi Reksa Dana Syariah). Selain itu, keuntungan yang akan dibagikan oleh penerbit sukuk ijarah harus bersumber dari hasil usaha/pengelolaan sukuk ijarah itu sendiri.

Untuk dapat melakukan kontrak sukuk berbasis ijarah, para investor, penerbit sukuk dan pihak terkait lainnya wajib memenuhi sejumlah persyaratan tertentu. Pertama, kedua belah pihak yang akan melakukan akad harus berkemampuan dan berakal. Kedua, akil baligh sebagaimana yang disyaratkan oleh Imam Asy Syafi'i dan Hambali. Sehingga berakad dengan anak kecil dinyatakan tidak sah.

Kemudian, agar transaksi berbasis ijarah tersebut menjadi sah (valid), diperlukan pula sejumlah ketentuan tambahan. Pertama, adanya kerelaan kedua belah pihak yang melakukan akad sebagaimana Firman Allah SWT pada Surah An-Nisa ayat 29. Kedua, mengetahui secara sempurna manfaat dari barang yang menjadi objek akad antara lain untuk mencegah terjadinya perselisihan. Ketiga, barang atau asset yang menjadi objek akad dapat dimanfaatkan sesuai dengan kriteria, realita dan syara. Imam Hanafi menambahkan bahwa menyewakan barang yang tidak dapat dibagi (tidak dalam keadaan lengkap) tidak dapat diperbolehkan, sebab manfaat kegunaannya tidak dapat ditentukan. Keempat, aset tersebut sudah jelas, nyata dan dimiliki penerbit sukuk sehingga dapat disewakan untuk diambil manfaatnya. Menyewakan binatang buruan (masih dalam perburuan), tanah tandus atau menyewakan binatang lumpuh yang tidak dapat diserahkan tidak dibenarkan secara syariah karena tidak mendatangkan

${ }^{27}$ Nurul Huda dan Mustafa Edwin Nasution, 2007. Investasi Pada Pasar Modal Syariah, Kencana, Jakarta. 
kegunaan yang menjadi obyek dari akad ini. Terakhir, sewa-menyewa yang dilakukan bukan untuk sesuatu yang diharamkan. Menyewakan asset yang akan digunakan untuk memproduksi minuman keras, tempat berjudi, dll tidak dibenarkan dalam syariah dan kontrak ijarah yang dilakukan menjadi ijarah fasid.

Hal terakhir yang spesifik dan layak diketahui dari sukuk ijarah adalah kontrak ini dapat diperjualbelikan di pasar modal dengan harga yang ditentukan oleh kekuatan pasar. Kegiatan ekonomi, investasi serta risiko yang berhubungan dengan kesanggupan penyewa untuk membayar harga sewa serta biaya penjaminan dan pemeliharaan asset menentukan harga sukuk ijarah di pasar keuangan. Namun demikian, sukuk ijarah menawarkan suatu bentuk surat berharga yang fleksible dan marketable dibandingkan jenis sukuk lainnya. ${ }^{[28]}$

\section{Sukuk Ijarah SBSN (Surat Berharga Syariah Negara)/ Sukuk Negara}

Ijarah telah menjadi suatu bentuk aktivitas ekonomi, terutama dalam dunia perbankan modern, maka telah terjadi perubahan teknis pada kontrak ijarah, meskipun asasnya secara umum tidak berubah. Pakar ekonomi telah mengembangkan akad ijarah yang lebih atraktif, yang sesuai dengan kaidah fiqih serta menyesuaikannya dengan mekanisme pasar yang relevan dengan kontrak pembiayaan modern. Pakar ekonomi juga telah mengembangkan teori ijarah dalam bentuk perbankan dan pasar modal. Kontrak ijarah yang dikembangkan dalam bentuk pasar modal lebih dikenal dengan sukuk ijarah (Islamic leasing certificates).

Dengan menggunakan skema ijarah sale and lease back, pemerintah menggunakan perusahaan penerbit dalam penerbitan sukuknya, maka untuk penerbitan SBSN ini, pemerintah akan menjual hak manfaat (beneficial title) asetnya kepada perusahaan penerbit. Perusahaan penerbit kemudian menerbitkan sukuk yang dijual kepada investor. Pemerintah memperoleh dana hasil penjualan aset tersebut dari investor melalui perusahaan penerbit. Aset yang telah dibeli oleh perusahaan penerbit disewakan kepada pemerintah.

Selama masa SBSN, pemerintah membayar sewa aset tersebut secara periodik kepada investor. Sukuk yang telah dimiliki investor bisa diperdagangkan di pasar sekunder menggunakan harga pasar. Pada saat jatuh tempo, pemerintah membeli kembali aset yang dijual kepada perusahaan penerbit melalui agen pembayar. Sertifikat sukuk yang dipegang oleh investor dikembalikan kepada perusahaan penerbit. Dengan menggunakan skema seperti ini (ijarah sale and leaseback), aliran kas investor tidak ada bedanya dengan jenis obligasi konvensional yang menawarkan bunga tetap atau variabel. Di mana, investor akan menerima pendapatan secara periodik kepada investor dalam bentuk pambayaran sewa pemerintah atas hak manfaat aset yang digunakan. Tapi tentunya, sukuk dengan skema ijarah sale and lease back telah sesuai dengan prinsip syariah yang terbebas dari larangan riba (bunga), gharar (ketidakpastian) dan maysir (spekulasi).

Sukuk ijarah termasuk jenis sukuk yang paling diminati oleh investor sehingga sukuk ijarah ini berkembang sedemikian cepat di pasaran. Sukuk ijarah merupakan produk yang terakhir yang 
tumbuh dengan cepat dalam pasar modal. Permintaan yang tinggi oleh investor dan institusi pembiayaan Islam menyebabkan sukuk ijarah ini semakin berkembang.

\section{KESIMPULAN}

Perkembangan sistem perekonomian di Indonesia dengan menggunakan akad ijarah mengalami perkembangan yang cukup pesat. Ijarah adalah akad pemindahan hak guna atas barang atau jasa, melalui pembayaran upah sewa, tanpa diikuti dengan pemindahan kepemilikan atas barang itu sendiri. Dalam hukum islam, istilah orang yang menyewakan disebut mu'jir, sedangkan orang yang menyewa/ penyewa disebut musta'jir, dan benda yang disewakan disebut majur, serta uang sewa atau imbalan atas pemakaian manfaat barang disebut ujrah. Masingmasing pihak harus memenuhi prestasi dalam pemenuhan akad ijarah ini dan resiko mengenai objek perjanjian dipikul oleh pemilik barang (pihak yang menyewakan), sebab penyewa hanya mengusai untuk mengambil manfaat atau kenikmatan dari barang yang disewakan. Sehingga dalam hal terjadi kerusakan objek perjanjian maka resiko ditanggung oleh pemilik barang, kecuali kerusakan yang terjadi disebabkan oleh adanya kesalahan penyewa.

Dalam perkembangan selanjutnya, ternyata akad ijarah tidak hanya digunakan dalam sistem perbankan syariah saja, melainkan dalam sistem pasar modal syariah. Penerapan ini menciptakan inovasi dalam prinsip-prinsip ijarah, seperti akad ijarah muntahiah bit tamlik, sukuk ijarah dan sukuk ijarah SBSN yang pada pelaksanaannya telah ada beberapa aturan khusus yang mengatur hal tersebut untuk tetap berdasarkan prinsip syariah.

\section{DAFTAR PUSTAKA}

\section{A. Buku}

Abdul Wahid, Nazaruddin, Sukuk: Memahami dan Membedah Obligasi pada Perbankan Syariah, 2010, Ar-Ruzz Media, Yogyakarta

Anshori, Abdul Ghofur. 2006. Pokok-pokok Hukum Perjanjian Islam di Indonesia, Citra Media, Yogyakarta.

Anwar, Syamsul, Hukum Perjanjian Syariah Studi tentang Teori Akad dalam Fikih Muamalat, PT. RajaGrafindo Persada: Jakarta, 2007

Ascara, 2008, Akad dan Produk Bank Syariah, Jakarta: PT Raja Grafindo Persada

DSN-MUI bersama BI, Himpunan Fatwa Dewan Syariah Nasional untuk Lembaga Keuangan Syariah, Edisi Pertama, 2001, Jakarta: DSN-MUI bersama BI

Karim, Adiwarman, Bank Islam Analisis Fiqih dan Keuangan, Edisi Ketiga, Rajawali Pers: Jakarta, 2007

Khairandy, Ridwan, 2004, Itikad Baik dalam Kebebasan Berkontrak, Program Pascasarjana Fakultas Hukum Universitas Indonesia: Jakarta

Mardani, Hukum Ekonomi Syariah di Indonesia, Refika Aditama: Jakarta, 2010

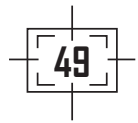


Nadhira Wahyu Adityarani \& Lanang Sakti | Tinjauan Hukum Penerapan Akad Ijarah Dan Inovasi

Remy Sjahdeini, Sutan, Perbankan Islam dan Kedudukannya dalam Tata Hukum Perbankan Indonesia, Grafiti: Jakarta, 1999

Suhendi, Hendi, Fiqh Muamalah Membahas Ekonomi Islam Kedudukan Harta, Hak Milik, Jual-beli, Bunga dan Riba, Musyarakah, Ijarah, Mudayanah, Koperasi, Asuransi, Etika Binis dll, Rajawali Press: Jakarta, 2011

Sunggono, Bambang, Metodologi Penelitian Hukum, PT RajaGrafindo Persada, Jakarta, 2003

Subekti, Aneka Perjanjian, Cetakan Kesepuluh, PT. Citra Aditya Bakti: Bandung, 1995

Syaf'i Antonio, Muhammad, Bank Syariah: Dari Teori ke Praktik, GemaInsani Press: Jakarta, 2001

Wiroso, Jual-beli Murabahah, UII Press: Yogyakarta, 2005

\section{B. Peraturan Perundang-Undangan}

Pemerintah Indonesia, Undang-Undang Nomor 21 tahun 2008 tentang Perbankan Syariah. Lembaran Negara RI Tahun 2008 No. 94

\section{Jurnal}

Wiwoho, Jamal, 2014, "Peran Lembaga Keuangan Bank dan Lembaga Keuangan Bukan Bank dalam Memberikan Distribusi Keadilan Bagi Masyarakat", Jurnal Masalah Masalah Hukum (MMH), Universitas Diponegoro, Vol. 43 No. 1, Semarang

\section{Website}

Website Bank Muamalat, Edukasi Perbankan, Mengenal Akad Perbankan Syariah, https://www. bankmuamalat.co.id/edukasi-perbankan/mengenal-akad-perbankan-syariah

Website Bank Muamalat, Tentang Profil Bank Muamalat, https://www.bankmuamalat.co.id/profilbank-muamalat 